Original Article

\title{
Production of proline and protease with different organic wastes in bacteria (Production proline and protease with organic wastes)
}

\author{
Produção de prolina e protease com diferentes resíduos orgânicos em bactérias \\ (produção de prolina e protease com resíduos orgânicos)
}

\author{
H. Kahraman ${ }^{a^{*}}$ (c) and C. C. Karaderib ${ }^{(0)}$ \\ a Inonu University, Faculty of Art and Sciences, Department of Biology, Malatya, Turkey \\ ${ }^{\mathrm{b}}$ Inonu University, Institute of Science, Department of Biology, Malatya, Turkey
}

\begin{abstract}
In this study, we investigated the proline and protease production of different bacteria in several organic waste materials. Our aim was to produce proline and protease economically in waste that is abundantly available while reducing its environmental impact. $5 \mathrm{ml}$ of different organic waste materials (OWW: Olive waste water; N.B: Nutrient Broth; EW: Eggshell; PBS: PBS buffer; PLW: Peach leaf wastes; TCW: Turkish coffee wastes; TWW: Tea waste water; WCW: Waste cheese whey; WFO: Waste frying oil) were placed in $10 \mathrm{ml}$ grow tubes, inoculated and incubated for $24 \mathrm{~h}$. Phosphate-buffered saline and $10 \%$ solutions of different organic wastes were added. These cultures were subsequently incubated at $37^{\circ} \mathrm{C}$ for $24 \mathrm{~h}$. Cells were harvested at $24 \mathrm{~h}$ for L-proline assay. $1 \mathrm{ml}$ of culture was transferred by pipette into an Eppendorf tube and centrifuged at 14,000 rpm for 20 min at room temperature. Cellular debris was removed by centrifuge and the supernatant was used for proline activity assays. Protease activity was determined using a modified method with casein as the substrate. We found that proline and protease can easily be produced economically using Turkish coffee wastes (TCW), Waste cheese whey (WCW) and Olive waste water (OWW) organic waste. We believe that this study will result in similar research leading to the economical use of these waste materials thus reducing their impact on the environment.
\end{abstract}

Keywords: organic wastes, bacteria, proline, protease.

\begin{abstract}
Resumo
Neste estudo, investigamos a produção de prolina e protease de diferentes bactérias em diversos resíduos orgânicos. Nosso objetivo era produzir prolina e protease economicamente em resíduos que estão disponíveis em abundância, reduzindo seu impacto ambiental. Cinco ml de diferentes materiais de resíduos orgânicos (OWW: resíduos de azeitona; NB: caldo nutriente; EW: casca de ovo; PBS: tampão PBS; PLW: resíduos de folhas de pêssego; TCW: resíduos de café turco; TWW: resíduos de chá; WCW: resíduos de queijo soro de leite; WFO: óleo de fritura residual) foram colocados em tubos de cultivo de $10 \mathrm{ml}$, inoculados e incubados por 24 horas. Adicionaram-se solução salina tamponada com fosfato e soluções a 10\% de diferentes resíduos orgânicos. Essas culturas foram subsequentemente incubadas a $37^{\circ} \mathrm{C}$ durante $24 \mathrm{~h}$. As células foram colhidas às $24 \mathrm{~h}$ para o ensaio de L-prolina. Um ml de cultura foi transferido por pipeta para um tubo Eppendorf e centrifugado a $14.000 \mathrm{rpm}$, por $20 \mathrm{~min}$, em temperatura ambiente. Os detritos celulares foram removidos por centrifugação e o sobrenadante foi usado para ensaios de atividade de prolina. A atividade da protease foi determinada usando um método modificado com caseína como substrato. Descobrimos que a prolina e a protease podem ser facilmente produzidas economicamente, usando resíduos de café turco (TCW), resíduos de soro de queijo (WCW) e resíduos orgânicos de água de oliva (OWW). Acreditamos que este estudo resultará em pesquisas semelhantes, levando ao uso econômico desses materiais residuais, reduzindo, assim, seu impacto no meio ambiente.
\end{abstract}

Palavras-chave: resíduos orgânicos, bactérias, prolina, protease.

\section{Introduction}

Microbial degradation, or biodegradation, appears to be the most environmentally friendly method of removing hydrocarbons. Other methods can result in toxic compounds entering the environment.
Pseudomonas aeruginosa floats with a single, polar, monotric flagellum rotating with proton motivating power. In the context of disease, this flagellar swimming motility is important in infection because the lack of

*e-mail: huseyin.kahraman@inonu.edu.tr

Received: September 04, 2020 - Accepted: November 10, 2020 
swimming ability of the $P$. aeruginosa mutant causes a decrease in pathogenesis (Lovewell et al., 2014; Murray and Kazmierczak, 2006).

Escherichia coli is a rod-shaped Gram (-) bacterium commonly found in the large intestines of warm-blooded animals (Goh et al., 2013) It is a model organism for the behavior of bacterial cell movement in mechanical and mass fluids. In particular, $E$. coli has been used as a prototypic micro-swimmer. The close motility of E. coli cells is important in the early stages of biofilm formation and pathogenic infection (Lauga et al., 2006). E. coli cells are important in the early stages of biofilm formation and pathogenic infection. E. coli cells have several extracellular, helical thread-like structures called flagella (Lauga et al., 2006; Mittal et al., 2003).

Bacillus cereus is a Gram (+), spore-forming, mobile, aerobic, rod-shaped and facultatively anaerobic bacterium. Bacillus subtilis is a soil bacterium that has a versatile metabolism and the ability to survive in various habitats. In nutritional research, it is known to enter the fusion motility as a cellular differentiation program when exposed to nutritional stress conditions (Granum and Lund, 1997; Ng, 2018).

Swarming migration has a bacterial action that can contribute significantly to the pathogenesis of Bacillus infection. Bacteria can be varied into prolonged, multi-core, hyper-flagellated swarmer cells that can move away from the colony in a coordinated manner along a moist, solid surface or in a viscous environment (Callegan et al., 2006).

Staphylococcus aureus is an anaerobic Gram (-) bacterium with a coke structure and causes widespread infections (Habib et al., 2015). It has been shown that S. aureus colonies can passively propagate along the surface of soft agar plates using a surfactant in a process called propagation (Pollitt et al., 2015).

Proteases are a group of enzymes commonly found in plants, animals, and microorganisms. Commercially important, they are used in silver recovery, industrial peptide synthesis, the hydrolysis of proteins in the food industry and for various applications in the textile industry. Proteases are also involved in the degradation of dead plant and animal tissues in aquatic and terrestrial environments. Bacterial proteases are more effective and practical than other cell proteases (Abusham et al., 2009; Ariole and Ilega, 2013; Kiran et al., 2006; Ramalakshmi et al., 2012; Jaffar Saleem, 2012; Tekin et al., 2012). Proteases also play a role in numerous pathological processes. Microbial proteases act like virulence factors and are known to damage the defense proteins of the host organism. Commonly used microorganisms for protease production include Streptococcus sp., Bacillus sp., Streptobacillus sp., P. aeruginosa, and E. coli (Alnahdi, 2012; Anbu, 2016; Maal et al., 2009; Vermelho et al., 1996).

Salinity is an important abiotic stress mechanism affecting microorganism growth and productivity (Troll and Lindsley, 1954). Under severe stress conditions, it can lead to growth inhibition or cell disruptions (Takagi, 2008)

No microorganism can actively pump water in or out of a cell to compensate for water fluxes caused by changes in external osmotic conditions (Brill et al., 2011). To survive these stresses most organisms have to stress-adaptation mechanisms. It's one of these things proline. To survive these stresses, most organisms have stress-adaptation mechanisms, one of which is proline (Bayat et al., 2014; Takagi, 2008).

In microorganisms, proline is synthesized from L-glutamic acid via three enzymatic reactions (Masuda et al., 1993). The proline is not only involved in protecting the intercellular structure and regulating the cytosolic $\mathrm{pH}$ but also in promoting protein integrity and activating enzyme activities. Proline is particularly important in prokaryotic and eukaryotic cells and has been reported to act as an osmolyte (Bayat et al., 2014; Jensen and Wendisch, 2013). Proline is an amino acid that increases in stress conditions, participates in the detoxification of free oxygen radicals and has protective properties that are important in resisting stress conditions (Holmström et al., 1996).In addition, in vitro studies have shown that proline has multiple functions in many organisms. It enhances the stability of proteins and membranes during freezing, dehydration, or high temperatures (Lovewell et al., 2014).

The aim of this study was to investigate the presence of $E$. coli, B. cereus, $S$. aureus and $P$. aeruginosa in various organic waste materials, to record survival levels and to measure the production of proline and protease.

\section{Materials and Methods}

\subsection{Reagents}

Glucose, Ninhidrin, $\mathrm{NaCl}, \mathrm{KCl}, \mathrm{Na}_{2} \mathrm{HPO}_{4}, \mathrm{KH}_{2} \mathrm{PO}_{4}$ Merck; Tris- $\mathrm{HCl}$, Casein, $\mathrm{Na}_{2} \mathrm{CO}_{3}$, Folin, Tyrosine Sigma-Aldrich; EDTA, Acetic acid Carlo Erba; NaOH, SDS Medico Chem; TCA Chem Bio; Nutrient Broth, Yeast Extract Lab M; Bacteriological peptone Mast Diagnostic. All chemicals were of the highest purity available commercially.

\subsection{Microorganism}

P. aeruginosa (ATCC 27853), E. coli (ATCC 25922), S. aureus (ATCC BAA 1026) and B. cereus (ATCC 10876) obtained from the ATCC and used this study.

\subsection{Organic wastes}

Waste cheese whey (WCW) was collected from commercial cheese factories in Malatya, Turkey.Waste frying oil (WFO) was obtained and collected from the food Restaurant Malatya, Turkey.Sugar beet molasses (SBM) was collected from Malatya Sugar Factories in Malatya, Turkey. These wastes were filtered for removing crude impurities and then, they're autoclaved, and then used. Others have supplied it ourselves because it is household waste (OWW: Olive waste water; EW: Eggshell; PBS: PBS buffer; PLW: Peach leaf wastes; TCW: Turkish coffee wastes; TWW: Tea waste water; WCW: Waste cheese whey; WFO: Waste frying oil).

\subsection{Growth conditions}

$P$. aeruginosa was cultivated in Luria- Bertani (LB) broth at $37{ }^{\circ} \mathrm{C}$, static on incubator for overnight $(\mathrm{O} / \mathrm{N})$. 
$100 \mu$ l of overnight cultures was setting $\mathrm{OD}_{600} \mathrm{~nm}$ of 0.2 0.3 grown tube and filled with $5 \mathrm{ml}$ in $10 \mathrm{ml}$ tubes was inoculated, and incubated for $24 \mathrm{~h}$ of time. These cultures were subsequently incubated on $37^{\circ} \mathrm{C}$ for $24 \mathrm{~h}$. Bacterial growth was determined by measuring the absorbance at $600 \mathrm{~nm}\left(\mathrm{OD}_{600}\right)$ by a visible spectrophotometer.

\subsection{L-Proline assay}

Bacteria were grown in a $10 \mathrm{ml}$ flask containing $100 \mathrm{ml}$ of LB medium. These cultures grew at $37{ }^{\circ} \mathrm{C}$ for $24 \mathrm{~h}$. For L-proline assay, cells were harvested at $24 \mathrm{~h}$ growth phase. $1 \mathrm{ml}$ culture was pipetted ependorf tube and centrifuged at $14.000 \mathrm{rpm}$ for $20 \mathrm{~min}$ at room temperature, cellular debris was removed by centrifugation, and the supernatant was then used for prolin activity assays (Troll and Lindsley, 1954).

After centrifugation supernatant was discarded and then on pellet $100 \mu \mathrm{l} \mathrm{GTE} \mathrm{buffer} \mathrm{(glucose,} \mathrm{Tris-HCl,} \mathrm{EDTA)}$ was added. Later room conditions were held for $1 \mathrm{~min}$ and then $200 \mu$ lysis buffers was added and 5 min stay room temperature. Over $500 \mu \mathrm{l}$ acidic ninhidrin was added. The tubes were kept in boiling water for 30 minutes. After tubes were then cooled. The mixture was pipettes into new set tubes, and $2 \mathrm{ml}$ benzene was added. The mixed in tubes gently vortexed and left at room temperature for $1 \mathrm{~h}$ until separation of the different two phases. The aqueous phase (i.e., the lower phase) was discarded by dipping a pipette through the organic phase add new tubes (i.e., the upper phase). Each sample reads at $\mathrm{OD}_{520} \mathrm{~nm}$ against using benzene a blank (Sugiura et al., 1985; Troll and Lindsley, 1954). The proline concentration in samples was determined from a predetermined standard curve using proline.

\subsection{Protease activity assay}

Protease activity was determined using a modified method with casein as the substrate. It was incubated at $37{ }^{\circ} \mathrm{C}$ for 24 hours. The absorbance was read at $\mathrm{OD}_{660} \mathrm{~nm}$ using Spectrophotometer (Ariole and Ilega,
2013; Maghsoodi et al., 2013; Mahanta et al., 2008; Ramalakshmi et al., 2012).

$\varepsilon=\left(\Delta A^{\circ} / \mathrm{min}\right) / 0.6896$ (This formula is used in calculation) (Liburdi et al., 2010).

\section{Results}

The main objective of this study was to evaluate organic residues, examine their potential as media and to investigate the viability of certain parameters such as proline and protease production. NB was used for $(+)$ control and PBS for (-) control. All study results were obtained after 24 hours.

\subsection{Proline}

We evaluated various organic waste materials (e.g. OWW: Olive waste water; EW: Eggshell PLW: Peach leaf wastes; TCW: Turkish coffee wastes; TWW: Tea waste water; WCW: Waste cheese whey; WFO: Waste frying oil) found in the environment. The focus was on the production of proline and protease, which are commercially important and necessary to protect the environment.

Excluding the control media, Gram (+) bacteria showed higher proline production than Gram (-) bacteria. B. cereus produced $4.996 \mu \mathrm{g} / \mathrm{ml}$ proline in the presence of PLW (Figure 1). The lowest production was seen in P. aeruginosa with $0.24 \mu \mathrm{g} / \mathrm{ml}$ in the presence of TWW (Figure 2). However, on average Gram (-) bacteria in this study showed higher proline production. In our previous study in LB medium, we obtained $5.071 \mu \mathrm{g} / \mathrm{ml}$ in E. coli (Figure 3) and $1.337 \mu \mathrm{g} / \mathrm{ml}$ in P. aeruginosa (Figure 2). In the same medium, we obtained $2.395 \mu \mathrm{g} / \mathrm{ml}$ in E. coli (Figure 3) and $9.226 \mu \mathrm{g} / \mathrm{ml}$ in P. aeruginosa (Figure 2).

In our study, the highest production was observed in $B$. cereus with molasses at $4.381 \mu \mathrm{g} / \mathrm{ml}$ and in the presence of WCW (Figure 1) in S. aureus with $2.074 \mu \mathrm{g} / \mathrm{ml}$ (Figure 4), excluding NB and PBS media used for control.

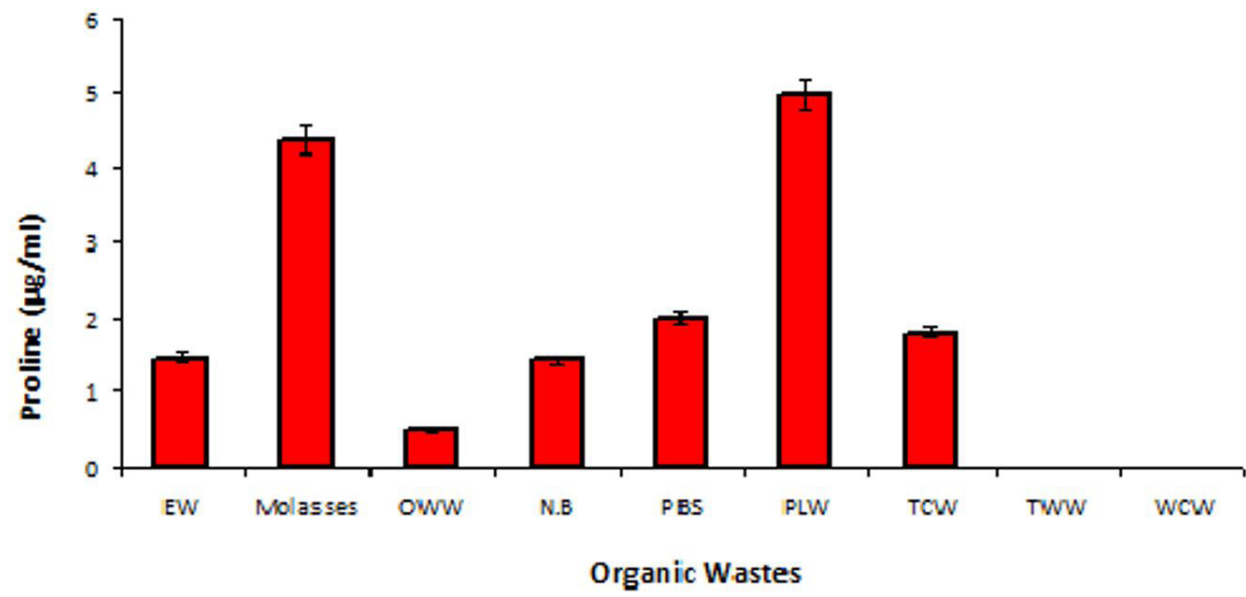

Figure 1. Proline levels of $B$. cereus in different organic wastes. 


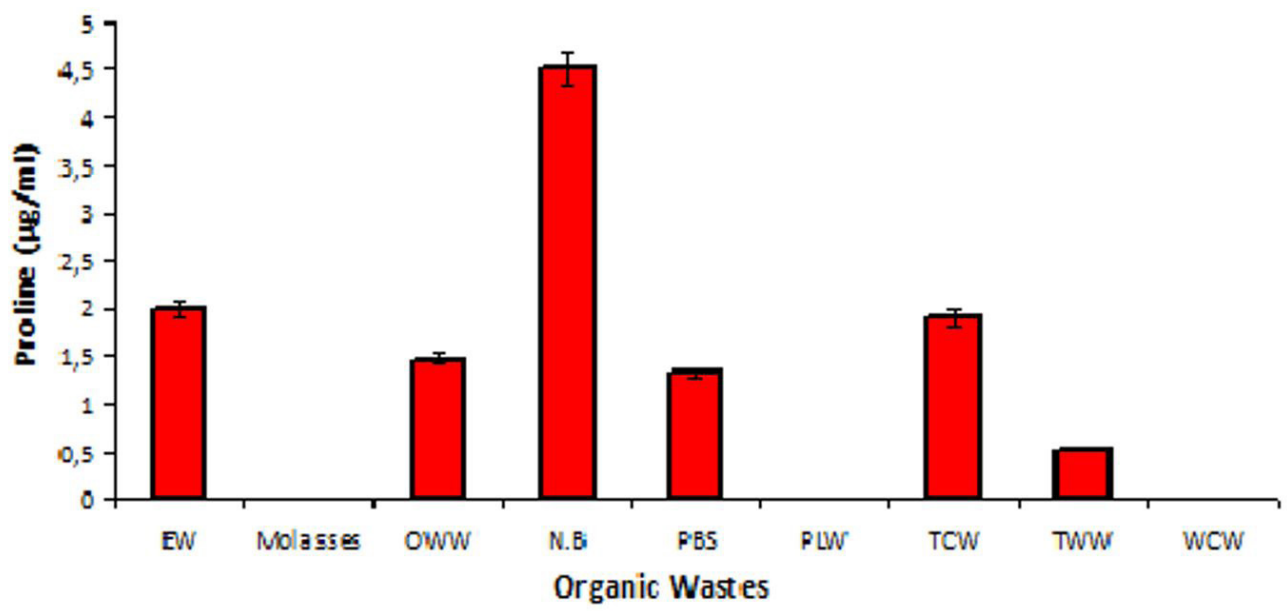

Figure 2. Proline levels of $E$. coli in different organic wastes.

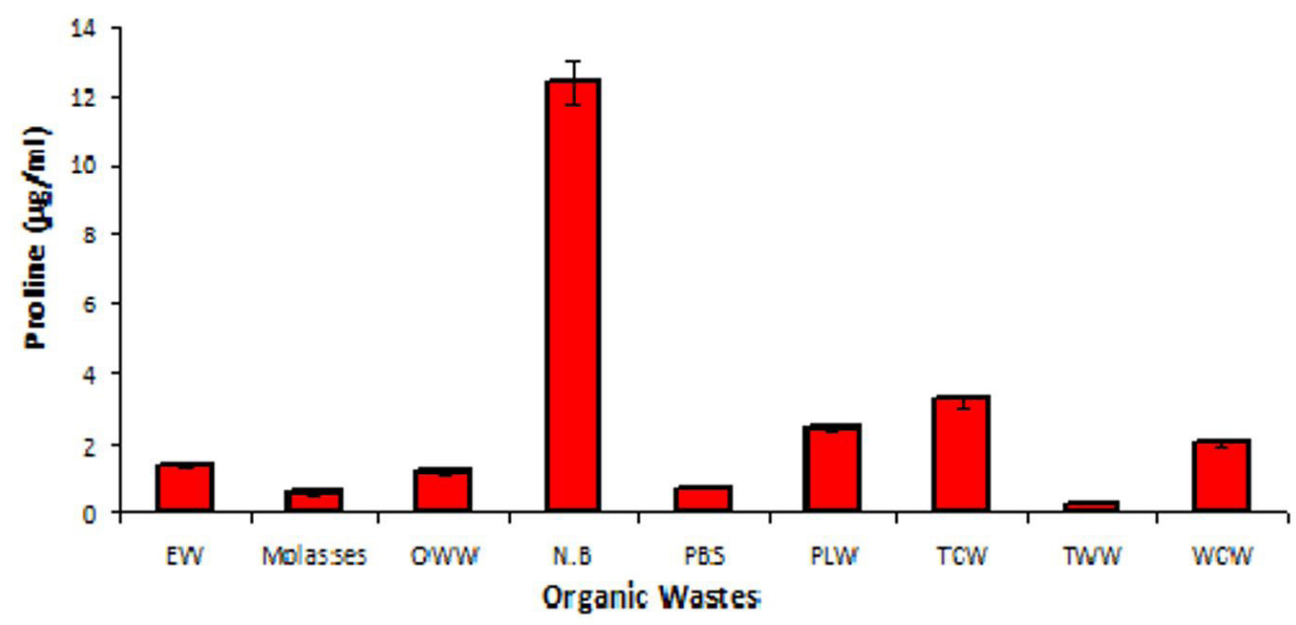

Figure 3. Proline levels of $P$. aeruginosa in different organic wastes.

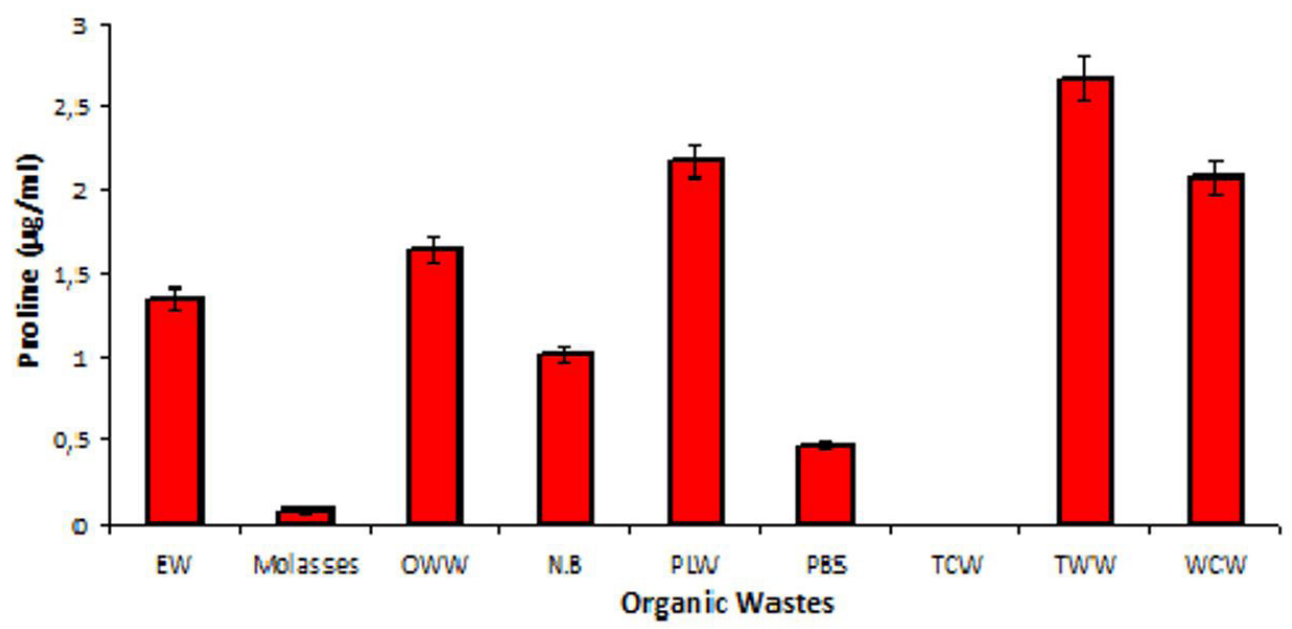

Figure 4. Proline levels of S. aureus in different organic wastes. 
The most efficient medium for E. coli was eggshell with $1.982 \mu \mathrm{g} / \mathrm{ml}$ (Figure 3). For P. aeruginosa, it was TCW medium with $3.27 \mu \mathrm{g} / \mathrm{ml}$ (Figure 2). Considering all environments, the most efficient in the study were eggshell and OWW. The most effective waste materials for proline production were TCW with $1.738 \mu \mathrm{g} / \mathrm{ml}$ average and molasses with $1.250 \mu \mathrm{g} / \mathrm{ml}$ average (Figure 1). The most ineffective waste was TWW with an average of $0.859 \mu \mathrm{g} / \mathrm{ml}$ (Figure 4). The most effective proline producing bacteria were $P$. aeruginosa with an average of $2.551 \mu \mathrm{g} / \mathrm{ml}$ (Figure 2). All bacteria produced an average of $1.738 \mu \mathrm{g} / \mathrm{ml}$ proline in the presence of TCW (Figures 1 and 3). The lowest amount of organic waste was obtained in the presence of TWW with an average of $0.859 \mu \mathrm{g} / \mathrm{ml}$. While $P$. aeruginosa produced $2.551 \mu \mathrm{g} / \mathrm{ml}$ proline on average in all environments (Figure 2), S. aureus produced the lowest amount with $0.993 \mu \mathrm{g} / \mathrm{ml}$ (Figure 4).

Since no research similar to our study was found in the literature, no comparison could be made with other studies. This study was conducted with different biological waste materials. We believe that microbiological proline production can be achieved practically and economically thus benefiting the environment.

As has been shown in previous tests (mostly on plants), proline is a response to stress in living organisms. For unknown reasons, negative changes were observed in $E$. coli and B. cereus. The biggest changes were seen in S. aureus (4.4-fold) (Figure 4) followed by P. aeruginosa with 2.9-fold (Figure 2). WCW did not materially increase stress response. This may result from the lack of adequate components for proline production in WCW and the weakness of the protein-produced metabolic pathways in bacteria.

When the control media are excluded, the lowest proline production was in TWW at $0.24 \mu \mathrm{g} / \mathrm{ml}$ (Figure 1) and the highest in TCW at $3.27 \mu \mathrm{g} / \mathrm{ml}$ (Figure 2). The difference was 13.6-fold.
When we look at proline production in the presence of organic waste, the highest value $(+)$ were reached with $12.38 \mu \mathrm{g} / \mathrm{ml}$ in NB medium (Figure 4), which we used as control. $0.69 \mu \mathrm{g} / \mathrm{ml}$ were obtained in (-) control PBS (Figure 4). Inhibition was seen in TWW $(0.24 \mu \mathrm{g} / \mathrm{ml})$ (Figure 1 ) and molasses $(0.55 \mu \mathrm{g} / \mathrm{ml}$ ) (Figure 3$)$. In the presence of the remaining organic waste materials (OWW, TCW, and WCW), values of $1.26,3.27$ and $2.02 \mu \mathrm{g} / \mathrm{ml}$ was obtained, respectively (Figure 4). However, no value could be obtained in the presence of WFO (not shown on the graph). This is interesting and may be due to the high carbohydrate load. These results show that the protein load in organic waste is important in proline production. TCW, WCW, and OWW are organic wastes that support proline production.

\subsection{Protease}

Protease is a virulence factor and a secondary metabolite. No protease production was detected in our study on EW and PLW so they are not shown on the graph. Unlike proline production, protease activity was higher in Gram (-) bacteria. However, the highest value in (-) control PBS was $0.104 \mathrm{U} / \mathrm{ml}$ while no results in $(+)$ control NB were obtained in these experiments.

In our previous study with LB medium in E. coli and P. aeruginosa, $0.401 \mathrm{U} / \mathrm{ml}$ and $0.2976 \mathrm{U} / \mathrm{ml}$ values were obtained, respectively. In our study, the highest protease production in WCW with high protein load was in E. coli (Figure 5). However, when we looked proportionally, it was clear that the highest difference was in P. aeruginosa at 67.5 times (Figure 6). Why did E. coli produce the most despite this huge difference? This may have resulted from the metabolic load caused by the large genome of $P$. aeruginosa close to yeasts (Figure 6). The lowest rate was seen in S. aureus (0.31) (Figure 7) and the lowest difference in B. cereus (3.3-fold) (Figure 8). We think this is because $B$. cereus is soil bacteria and

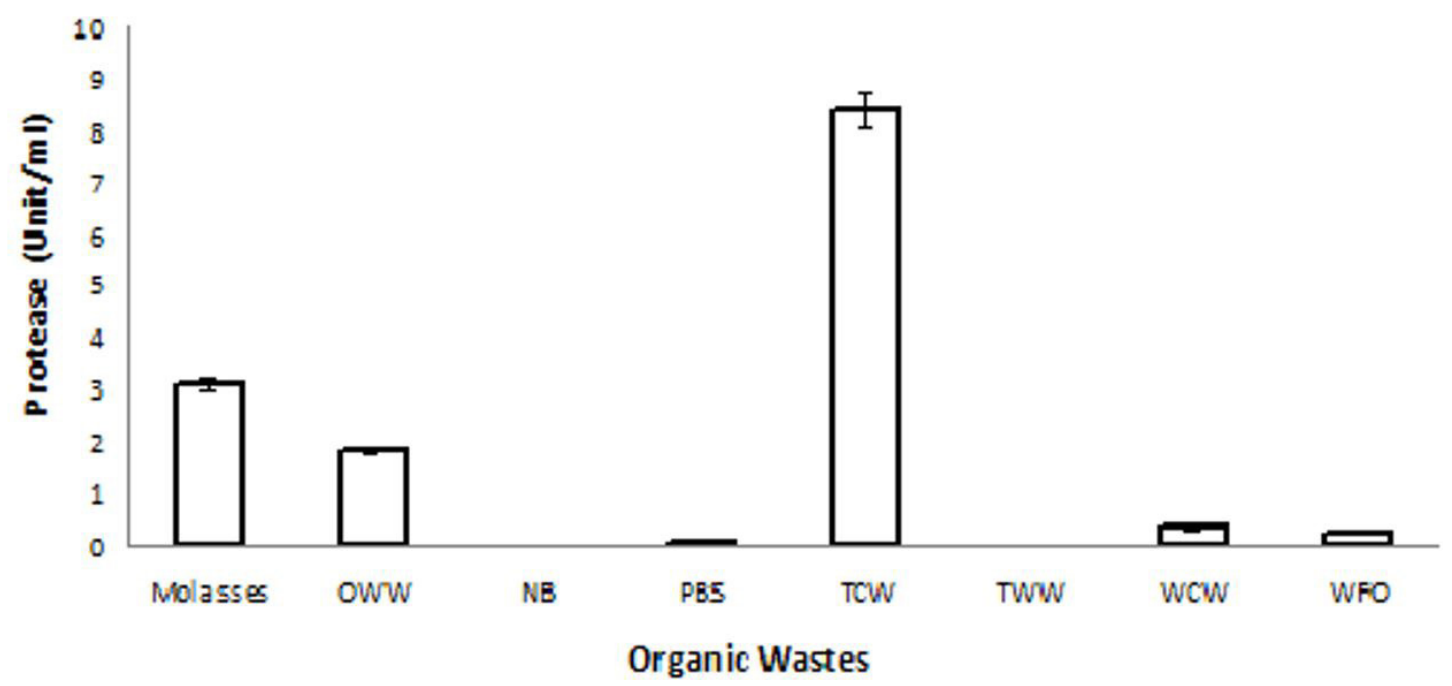

Figure 5. Protease levels of B. cereus in different organic wastes. 


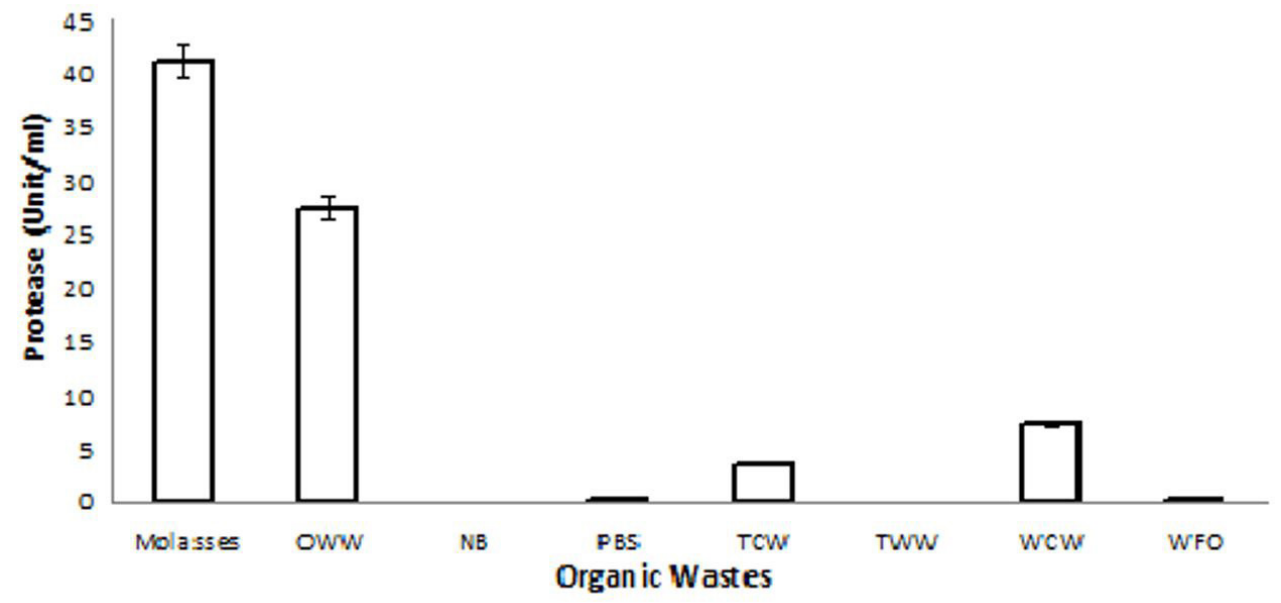

Figure 6. Protease levels of $E$. coli in different organic wastes.

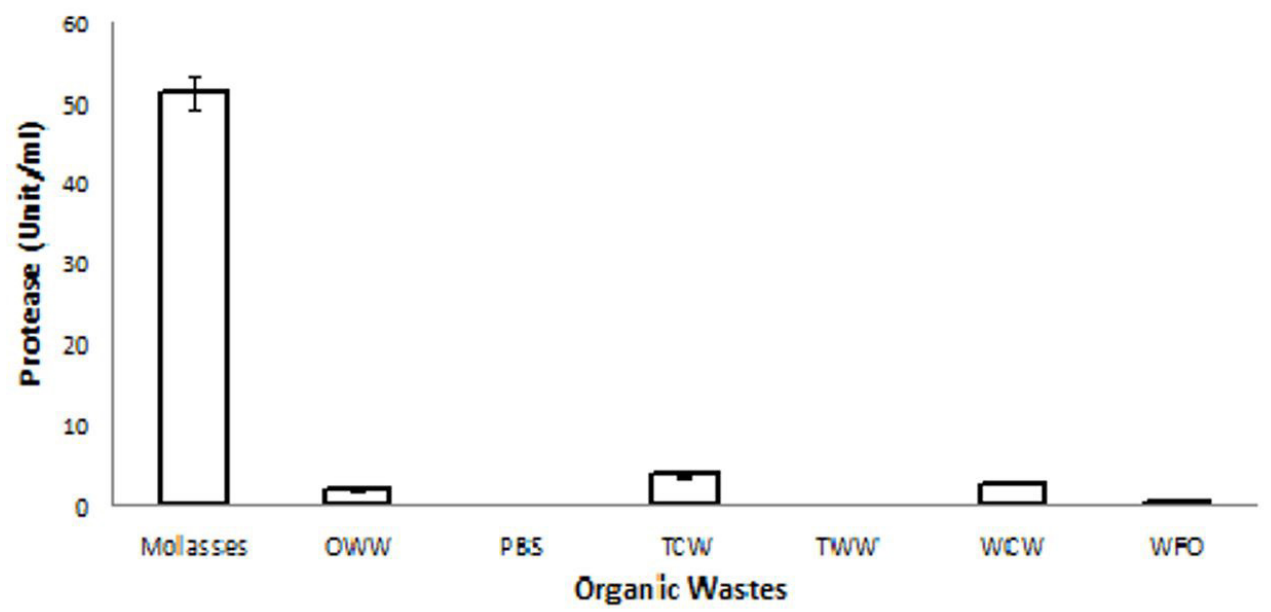

Figure 7. Protease levels of $P$. aeruginosa in different organic wastes.

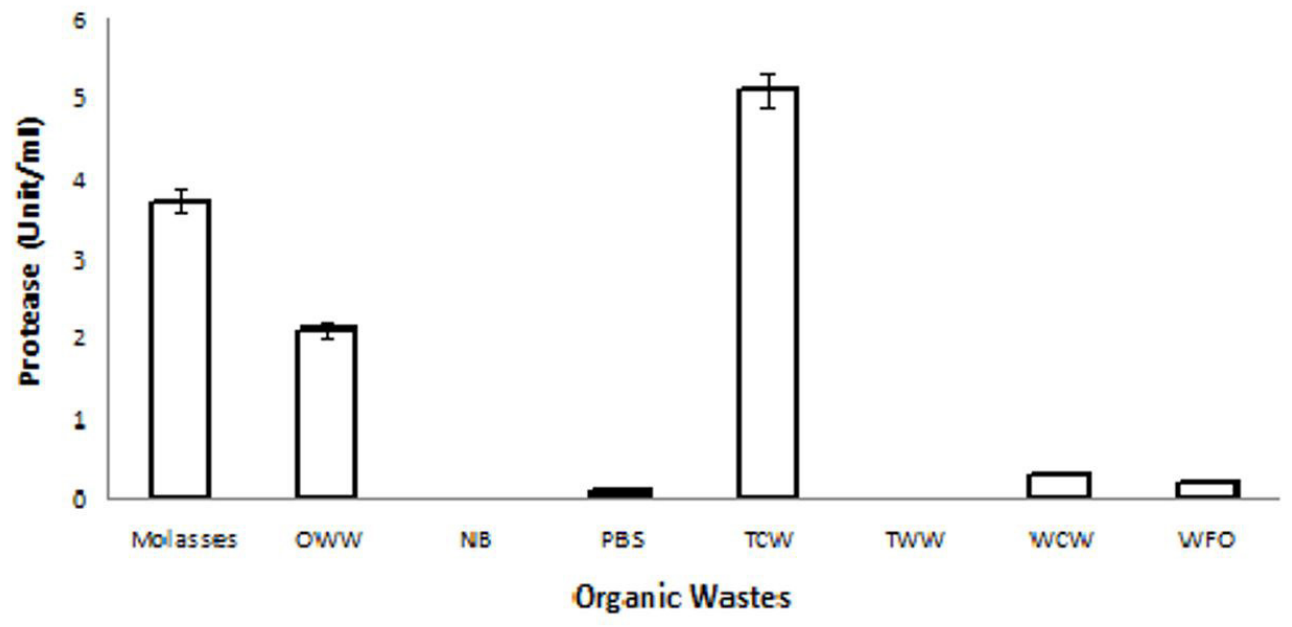

Figure 8. Protease levels of S. aureus in different organic wastes. 
protease activity may not be much needed in the soil environment. However, other bacteria may have higher protease activity than $B$. cereus because of their ability to survive in living organisms.

The highest values were observed in $P$. aeruginosa at $51.347 \mathrm{U} / \mathrm{ml}$ (Figure 6) and in E. coli in the presence of molasses at $47.182 \mathrm{U} / \mathrm{ml}$ (Figure 4). The highest subsequent rate was $27.297 \mathrm{U} / \mathrm{ml}$ in the presence of OWW (Figure 7). B. cereus reached the highest value in the presence of TCW with $8.394 \mathrm{U} / \mathrm{ml}$ (Figure 8). S. aureus reached $3.717 \mathrm{U} / \mathrm{ml}$ (Figure 7), again in the presence of molasses. The most efficient medium was molasses with a high carbohydrate load. The highest average for all four bacteria, $24.841 \mathrm{U} / \mathrm{ml}$, was reached in the presence of molasses with a high hydrate load. Protease production in the last three environments was the lowest: WFO 0.261 with $B$. cereus (Figure 8 ), $0.170 \mathrm{U} / \mathrm{ml}$ P. aeruginosa (Figure 6) in the same organic waste and $0.159 \mathrm{U} / \mathrm{ml}$ S. aureus (Figure 7).

The lowest average was in the presence of WFO with $0.215 \mathrm{U} / \mathrm{ml}$, excluding controls (Figure 7). E. coli yielded the highest mean value of $13.326 \mathrm{U} / \mathrm{ml}$ in all media (Figure 4). The lowest average production was in S. aureus at $1.9 \mathrm{U} / \mathrm{ml}$ (Figure 7). The three most successful bacteria were $P$. aeruginosa with $51.35 \mathrm{U} / \mathrm{ml}$ (Figure 8) and E. coli with $41.182 \mathrm{U} / \mathrm{ml}$ in the presence of molasses and E. coli with $27.297 \mathrm{U} / \mathrm{ml}$ in the presence of OWW (Figure 5). The most efficient production waste environment was molasses with an average of $24.81 \mathrm{U} / \mathrm{ml}$ (Figure 7) and OWW with an average of $8.288 \mathrm{U} / \mathrm{ml}$ (Figure 6). When all waste materials were evaluated separately, the most effective production among bacteria was $E$. coli with an average of $13.326 \mathrm{U} / \mathrm{ml}$ (Figure 5).

\section{Discussion}

Protease activity was approximately 23-fold higher than proline activity. The $\mathrm{OD}_{600}$ value (data not shown) increased by $314 \%$ and the increase in the number of living cells was reached $1,816 \%$. According to these results, cells may be more viable and transparent.

We believe that protease production from organic waste is also important for environmental protection so we focused on the organic wastes mentioned above. This study showed that proline and protease can both be produced economically and practically from TCW, WCW and OWW organic waste. We believe that this study will result in similar new research leading to the practical and economic use of waste material thus benefiting the environment. We think that this study will lead to similar new studies. At the same time, we think that the way to bring these wastes into the economy will be opened and the environment will be protected.

\section{References}

ABUSHAM, R.A., RAHMAN, R.N.Z.R.A., SALLEH, A.B. and BASRI, M., 2009. Optimization of physical factors affecting the production of thermo-stable organic solvent-tolerant protease from a newly isolated halo tolerant Bacillus subtilis strain Rand. Microb.
Microbial Cell Factories, vol. 8, no. 20, pp. 1-9. http://dx.doi. org/10.1186/1475-2859-8-20. PMid:19356254.

ALNAHDI, H.S., 2012. Isolation and screening of extracellular proteases produced by new Isolated Bacillus sp.Journal of Applied Pharmaceutical Science, vol. 2, pp. 71-74. http://dx.doi.org/10.7324/JAPS.2012.2915.

ANBU, P., 2016. Enhanced production and organic solvent stability of a protease from Brevibacillus laterosporus strain PAP04. Brazilian Journal of Medical and Biological Research, vol. 49, no. 4, pp. 1-7. http://dx.doi.org/10.1590/1414-431X20165178. PMid:27007657.

ARIOLE, C.N. and ILEGA, E., 2013. Alkaline protease production by Pseudomonas aeruginosa isolated from the gut of Pila ovata. Journal of Global Bioscience, vol. 2, pp. 126-131.

BAYAT, R.A., KUŞVURAN, Ş, ELLIALTIOǦLU, Ş and ÜSTÜN, A.S., 2014. Effects of proline application on antioxidative enzymes activities in theyoung pumpkin plants (Cucurbita pepo L. and C. moschata Poir.) under salt stress. Türk Tarrm ve Doğa Bilimleri Dergisi, vol. 1, no. 1, pp. 25-33.

BRILL, J., HOFFMANN, T., BLEISTEINER, M. and BREMER, E., 2011. Osmotically controlled synthesis of the compatible solute proline is critical for cellular defense of Bacillus subtilis against high osmolarity. Journal of Bacteriology, vol. 193, no. 19, pp. 53355346. http://dx.doi.org/10.1128/JB.05490-11. PMid:21784929.

CALLEGAN, M.C., NOVOSAD, B.D., RAMIREZ, R., GHELARDI, E. and SENESI, S., 2006. Role of swarming migration in the pathogenesis of Bacillus endophthalmitis. Investigative Ophthalmology \& Visual Science, vol.47, no. 10, pp. 4461-4467. http://dx.doi.org/10.1167/ iovs.06-0301. PMid:17003440.

GOH, S.N., FERNANDEZ, A., ANG, S.-Z., LAU, W.-Y., NG, D.-L. and CHEAH, E.S.G., 2013. Effects of different amino acids on biofilm growth, swimming motility and twitching motility in Escherichia coli BL21. Journal of Biology and Life Science, vol. 4, no. 2, pp. 104-115. http://dx.doi.org/10.5296/jbls.v4i2.3195.

GRANUM, P.E. and LUND, T., 1997. Bacillus cereus and its food poisoning toxins. FEMS Microbiology Letters, vol. 157, no. 2, pp. 223-228. http://dx.doi.org/10.1111/j.1574-6968.1997.tb12776.x. PMid:9435100.

HABIB, F., RIND, R., DURANI, N., BHUTTO, A.L., BURIRO, R.S., TUNIO, A., AIJAZ, N., LAKHO, S.A., BUGTI, A.G. and SHOAIB, M., 2015. Morphological and cultural characterization of Staphylococcus aureus isolated from different animal species. Journal of Applied Environmental and Biological Sciences, vol. 5, no. 2, pp. 15-26.

HOLMSTRÖM, K., MÄNTYLÄ, E., WELIN, B., MANDAL, A., PALVA, E.T., TUNNELA, O.E. and LONDESBOROUGH, J., 1996. Drought tolerance in tobacco. Nature, vol. 379, no. 6567, pp. 683-684. http://dx.doi.org/10.1038/379683a0.

JENSEN, J.V.K. and WENDISCH, V.F., 2013. Ornithine cyclodeaminasebased proline production by Corynebacterium glutamicum. Microbial Cell Factories, vol. 12, no. 1, pp. 63-72. http://dx.doi. org/10.1186/1475-2859-12-63. PMid:23806148.

KIRAN, Ö.E., ÇÖMLEKÇIOǦLU, U. and DOSTBIL, N., 2006. Some microbial enzymes and usage fields in industry. KSU Journal of Science and Engineering, vol. 9, pp. 12-19.

LAUGA, E., DILUZIO, W.R., WHITESIDES, G.M. and STONE, H.A., 2006. Swimming in circles: motion of bacteria near solid boundaries. Journal of Biological Physics, vol. 90, no. 2, pp. 400-412. PMid:16239332.

LIBURDI, K., BENUCCI, I. and ESTI, M., 2010. Study of two different immobilized acid proteases for wine application. Food Biotechnology, vol. 24, no. 3, pp. 282-292. http://dx.doi.org/1 0.1080/08905436.2010.507158.

LOVEWELL, R.R., HAYES, S.M., O'TOOLE, G.A. and BERWIN, B., 2014. Pseudomonas aeruginosa flagellar motility activates the phagocyte PI3K/Akt pathway to induce phagocytic engulfment. American Journal of Physiology. Lung Cellular and Molecular 
Physiology, vol. 306, no. 7, pp. 698-707. http://dx.doi.org/10.1152/ ajplung.00319.2013. PMid:24487390.

MAAL, K.B., EMTIAZI, G. and NAHVI, I., 2009. Production of alkaline protease by Bacillus cereus and Bacillus polymixa in new industrial culture mediums and its immobilization. African Journal of Microbiological Research, vol. 3, pp. 491-497.

MAGHSOODI, V., KAZEMI, A., NAHID, P., YAGHMAEI, S. and SABZEVARI, M.A., 2013. Alkaline protease production by immobilized cells using $B$. licheniformis, production by immobilized cells using B. licheniformis. Scientia Iranica C, vol. 20, pp. 607-610.

MAHANTA, N., GUPTA, A. and KHARE, S.K., 2008. Production of protease and lipase by solvent tolerant Pseudomonas aeruginosa PseA in solid-state fermentation using Jatropha curcas seed cake as substrate. Bioresource Technology, vol. 99, no. 6, pp. 1729-1735. http://dx.doi.org/10.1016/j.biortech.2007.03.046. PMid:17509877.

MASUDA, M., TAKAMATU, S., NISHIMURA, N., KOMATSUBARA, S. and TOSA, T., 1993. Improvement of culture conditions for l-proline production by a recombinantstrain of Serratia marcescens. Applied Microbiology and Biotechnology, vol. 189, no. 43, pp. 189-197.

MITTAL, N., BUDRENE, E.O., BRENNER, M.P. and VAN OUDENAARDEN, A., 2003. Motility of Escherichia coli cells in clusters formed by chemotactic aggregation. Proceedings of the National Academy of Sciences of the United States of America, vol. 100, no. 23, pp. 13259-13263. http://dx.doi.org/10.1073/pnas.2233626100. PMid:14597724.

MURRAY, T.S. and KAZMIERCZAK, B.I., 2006. FlhF is required for swimming and swarming in Pseudomonas aeruginosa. Journal of Bacteriology, vol. 188, no. 19, pp. 6995-7004. http://dx.doi. org/10.1128/JB.00790-06. PMid:16980502.

NG, W., 2018. Retarded swarming motility in Bacillus subtilis NRS-762 and Pseudomonas aeruginosa PRD-10. Peer Journal of Preprints, pp. 1-10.
POLLITT, E.J.G., CRUSZ, S.A. and DIGGLE, S.P., 2015. Staphylococcus aureus forms spreading dendrites that have characteristics of active motility. Scientific Reports, vol. 5, no. 17698, pp. 1-12. PMid:26680153.

RAMALAKSHMI, N., NARENDRA, D., RAMALAKSHMI, M., ROJA, S., ARCHANA, B.K.N. and MAANASA, G., 2012. Isolation and characterization of protease producing bacterial from soil and estimation of protease by spectrophotometer. The Experiments, vol. 1, no. 1, pp. 1-7.

JAFFAR SALEEM, A., 2012. Relationship study between the alkaline protease production and the growth phases of Pseudomonas aeruginosa isolated from patients. Advances in Microbiology, vol. 2, no. 03, pp. 354-357.http://dx.doi.org/10.4236/aim.2012.23043.

SUGIURA, M., TAKAGI, T. and KISUMI, M., 1985. Proline production by regulatory mutantsof Serratia marcescens. Applied Microbiology and Biotechnology, vol. 21, no. 3-4, pp. 213-219. http://dx.doi. org/10.1007/BF00295125.

TAKAGI, H., 2008. Proline as a stress protectant in yeast: physiological functions, metabolic regulations, and biotechnological application. Applied Microbiology and Biotechnology, vol. 81, no. 2, pp. 211-223. http://dx.doi.org/10.1007/s00253-008-1698-5. PMid: 18802692.

TEKIN, N., CIHAN, A.C., TAKAÇ, Z.S., TÜZÜN, C.Y., TUNÇ, K. and ÇÖKMÜŞ, C., 2012. Alkaline protease production of Bacillus cohnii APT5. Turkish Journal of Biology, vol. 36, pp. 430-440.

TROLL, W. and LINDSLEY, J.A., 1954. Photometric method for the determination of prolin. The Journal of Biological Chemistry, vol. 215, no. 2, pp. 655-660. http://dx.doi.org/10.1016/S00219258(18)65988-5. PMid:13242563.

VERMELHO, A.B., MEIRELLES, M.N.L., LOPES, A., PETINATE, S.D.G., CHAIA, A.A. and BRANQUINHA, M.H., 1996. Detection of extracellular proteases from microorganisms on agar plate. Memorias do Instituto Oswaldo Cruz, vol. 91, no. 6, pp. 755760. http://dx.doi.org/10.1590/S0074-02761996000600020. PMid:9283660. 